\title{
ACQUISITION OF SYNTAX IN CHILD AGED FIVE YEARS (A CASE STUDY RESEARCH)
}

\author{
Dewi Indah Susanti \\ Universitas Indraprasta PGRI \\ Jatut Yoga Prameswari \\ Universitas Indraprasta PGRI \\ Jl. Nangka No. 58C Tanjung Barat, Jagakarsa, Jakarta Selatan, Kode Pos, Indonesia \\ e-mail: dewimughni@gmail.com
}

\begin{abstract}
The purpose of this study was to obtain information about the acquisition of syntactic child aged five year the research is a descriptive qualitative and research method is a case study with content analysis techniques. The subject of this study was one a five-year-old child, whose initial name was HGF, living in the South Jakarta area. Data collection techniques are done by observation and interview methods. Data in the form of audio and video recordings was then transcribed into written form. The data was listened and read repeatedly for later analysis. The most dominant syntactic acquisition results were phrase acquisition, which was $62.6 \%$ with details of the verb phrase $26.7 \%$, adjunctively phrases $8.6 \%$, noun phrases $12.2 \%$, prepositional phrases $15.1 \%$; acquisition of single sentences was $20.1 \%$; and obtaining compound sentences was $17.3 \%$.
\end{abstract}

Keywords: acquisition, syntax, children.

\begin{abstract}
Article History: Received: 24/01/2020; Revised: 2/06/2020; Accepted: 25/06/2020; Published: 16/07/2020
How to Cite (MLA 7 $^{\text {th }}$ ): Susanti, Dewi Indah dan Jatut Yoga Prameswari. "Acquisition of Syntax in Child Aged Five Years (A Case Study Research)." Hortatori Jurnal Pendidikan Bahasa dan Sastra Indonesia vol. 4 no. 1, 2020, 1-8. Print/Online. Copyrights Holder: Dewi Indah Susanti dan Jatut Yoga Prameswari. First Publication: Hortatori Jurnal Pendidikan Bahasa dan Sastra Indonesia (2020).
\end{abstract}

\section{Pendahuluan}

Orang pada umunya tidak merasakan bahwa menggunakan bahasa merupakan suatu keterampilan yang luar biasa rumitnya. Pemakaian bahasa terasa lumrah karena memang tanpa diajari oleh siapapun, seorang bayi akan tumbuh bersama pertumbuhan bahasanya. Pemakaian bahasa merupakan cerminan dari kemampuan yang hanya manusialah yang dapat melakukannya. Bagaimana manusia dapat mempersepsi dan kemudian memahami ujaran orang lain merupakan umur pertama yang harus dikuasai manusia dalam berbahasa. Begitu pula manusia hanya dapat memroduksi ujaran apabila ia mengetahui aturan-aturan yang harus diikuti yang ia peroleh sejak kecil.

Proses penguasaan bahasa yang dilakukan oleh anak secara natural pada waktu dia belajar bahasa ibunya (native language) disebut pemerolehan (acquisition) bahasa. Istilah pemerolehan dibedakan dengan pembelajaran yang merupakan padanan dari istilah Inggris, learning. Dalam pengertian ini proses itu dilakukan dalam tataran yanag formal, yakni belajar di kelas dan diajar oleh seorang guru. Dengan demikian maka proses dari anak yang yang belajar menguasai bahasa ibunya adalah pemerolehan, sedangkan proses dari orang (umunya dewasa) yang belajar di kelas adalah pembelajaran (Darjowidjojo, 2003:225).

Dalam artikel Wulandari (2018: 75-7) pemerolehan (acquisition) bahasa yang diteliti mengacu kepada pemerolehan bahasa Indonesia Anak Usia 3-5 Tahun di PAUD Lestari, Desa Blimbing, Kecamatan Paciran, Kabupaten Lamongan, paparan langsung (exposure) dalam situasi bahasa, proses berlangsung dalam otak anak ketika dia memeroleh bahasa ibu atau bahasa pertamanya. Sementara itu, 
pembelajaran (learning) mengacu pada aktivitas belajar secara sadar dan terprogram dalam situasi kelas formal dengan bantuan pengajar (guru). Artikel tersebut mengarah kepada pemerolehan bahasa Indonesia anak usia 3-5 tahun, dalam penelitian yang diteliti oleh peneliti adalah pemerolehan bahasa yang lebih spesifik lagi mengarah kepada pemerolehan sintaksis pada anak usia lima tahun

Dalam artikel Nurjamiaty (2015 : 47-48) Proses belajar bahasa pertama memiliki ciri-ciri: 1). belajar tidak disengaja 2). berlangsung sejak lahir, 3). lingkungan keluarga sangat menentukan 4). motivasi ada karena kebutuhan 5). banyak waktu untuk mencoba bahasa 6). banyak kesempatan untuk berkomunikasi. Pada proses belajar bahasa kedua terdapat ciri-ciri: 1). belajar bahasa disengaja, misalnya karena menjadi salah satu mata pelajaran di sekolah 2). berlangsung setelah pelajar berada di sekolah 3). lingkungan sekolah sangat menentukan 4. motivasi pelajar untuk mempelajarinya tidak sekuat mempelajari bahasa pertama. Motivasi itu misalnya ingin memperoleh nilai baik pada waktu ulangan atau ujian. 5). waktu belajar terbatas 6). pelajar tidak mempunyai banyak waktu untuk mempraktikan bahasa yang dipelajari. 7). bahasa pertama mempengaruhi proses belajar bahasa kedua 8). umur kritis mempelajari bahasa kedua kadang- kadang telah lewat sehingga proses belajar bahasa kedua berlangsung lama. 9). disediakan alat bantu belajar 10). ada orang yang mengorganisasikannya, yakni guru dan sekolah.

Saat ini banyak orang tua yang secara tidak sadar melupakan perkembangan bahasa anak, terutama pada tahapan sintaksisnya. Bagaimana anak memperoleh kata yang nantinya akan terangkai sebagai frasa, klausa, dan kalimat. Anak lebih asik dan fokus pada gawai yang pada akhirnya membuat pemerolehan sintaksis mereka terhambat. Selain itu, tidak intensnya proses komunikasi orang tua dan anak juga mempengaruhi pemerolehan sintaksis anak. Anak akan menyimak dan kemudian meniru apa yang mereka dengar dan diajarkan oleh orang tuannya. Tidak hanya itu latar belakang sosial ataupun akademik orang tua juga memengaruhi pemerolehan sintaksis pada anak usia lima tahun, hal ini didukung oleh pendapat Jenifer \& Hayes, 1999: 85 (Sari, 2015: 5) mengemukakan bahwa "keluarga merupakan institusi pendidikan yang dan utama. Pada awal sejarah, tidak ada institusi sekolah, anak mendapatkan pendidikan di keluarga langsung oleh orang tuanya masing-masing. Perkembangan teknologi dan kebutuhan manusia mendorong orang tua yang merasa kurang mampu membelajarkan anaknya secara optimal, maka lahirlah institusi pendidikan. Institusi lahir untuk membantu orang tua (keluarga) dalam mendidik anak-anak, sehingga keterhubungan yang harmonis antara pihak keluarga dan lembaga sangat diperlukan".

Pemilihan HGF sebagai subjek dalam penelitian karena kedekatan dengan subjek tersebut sehingga membuat proses penelitian dalam pemerolehan data lebih mudah, cepat, dan detail. Selain itu, keberadaannya yang dekat memudahkan peneliti melakukan pengamatan dan pengambilan data terhadap subjek tersebut. Berdasarkan hal tersebut di atas penelitian ini bertujuan untuk menganalisis pemerolehan bahasa pada anak usia lima tahun pada tataran pemerolehan sintaksis yang kaitannya dengan kata, frasa, klausa, dan kalimat.

\section{Metode}

Penelitian ini menggunakan jenis penelitian deskriptif kualitatif dengan analisis isi (content analysis). Penelitian kualitatif dengan ciri deskriptif menurut Bungin (2007 : 185) mensyaratkan data yang dikumpulkan berupa daftar ujaran (dalam hal ini berkaitan dengan rekaman video dan audio anak), dan bukan berupa angka. Metode yang digunakan adalah studi kasus, Penelitian kualitatif deskriptif adalah berupa penelitian dengan metode atau pendekatan studi kasus (case study). Penelitian ini memusatkan diri secara intensif pada satu objek tertentu yang mempelajarinya sebagai suatu kasus. Data studi kasus dapat diperoleh dari semua pihak yang bersangkutan, dengan kata lain dalam studi ini dikumpulkan dari berbagai sumber (Nawawi, 2003: 1). Seluruhnya data yang dikumpulkan berupa rekamana video dan audio yang berkemungkinan menjadi kunci terhadap apa yang sudah diteliti. Hasil penelitian ini nantinya berupa deskripsi disertai kutipan data yang berupa rekaman video dan audio dari daftar ujaran atau dialog yang dijadikan sebagai sampel, kemudian diberi interpretasi sesuai dengan aspek pemerolehan sintaksis.Subjek penelitian ini adalah salah satu anak yang berusia lima tahun, nama anak tersebut Husein HGF Fakhrusy (disingkat HGF), tinggal di daerah Jakarta Selatan.

Teknik pengumpulan data yang dilakukan adalah dengan metode observasi dan wawancara. Data dikumpulkan secara naturalistik dengan tambahan stimulasi untuk memunculkan respon tertentu dari responden. Data berupa rekaman audio dan video kemudian ditranskripsikan ke dalam bentuk tulisan. 


\section{Hasil dan Diskusi}

Sintaksis membicarakan penataan dan pengaturan kata-kata ke dalam satuan-satuan yang lebih besar, yang disebut satuan-satuan sintaksis, yakni kata, frasa, klausa, kalimat, dan wacana. Sajian untuk pemerolehan anak usia lima tahun dibagi menjadi dua bagian, yakni sajian mengenai perkembangan frasa dan sajian mengenai perkembangan kalimat. Metode yang digunakan adalah studi kasus, Penelitian kualitatif deskriptif adalah berupa penelitian dengan metode atau pendekatan studi kasus (case study). Penelitian ini memusatkan diri secara intensif pada satu objek tertentu yang mempelajarinya sebagai suatu kasus. Data studi kasus dapat diperoleh dari semua pihak yang bersangkutan, dengan kata lain dalam studi ini dikumpulkan dari berbagai sumber (Nawawi, 2003: 1).

\section{Perkembangan Frasa Anak Usia Lima Tahun}

Pada perkembangan frasa adjektiva, responden tercatat telah dapat memakai prefiks (-an) dengan benar, seperti tinggian, cantikkan, besaran, dsb yang berarti "lebih+adjektiva". Bentuk superlatif juga sudah responden pakai seperti pada frasa paling cantik, paling tinggi, paling gede, dsb, tetapi prefiks $\{$ teR- $\}$ bentu superlatif belum ditemukan dalam data.

Perkembangan frasa verba pada usia lima tahun sudah semakin banyak, unsur pewatas depan sudah banyak dikuasai responden, seperti mau makan, belum punya, sudah mandi, lagi main, dsb.

Perkembangan frasa nomina terlihat dalam dua bentuk: (1) penambahan pewatas dalam bentuk kata, dan (2) penambahan pewatas dalam bentuk klausa. Penjejeran dua nomina untuk membentuk frasa juga sudah ditemukan, seperti mobil polisi, kereta api, bola basket, dsb. Di samping penambahan kata sebagai pewatas, responden juga telah dapat membuat frasa nomina dengan memanfaatkan klausa relatif, seperti mau yang warna merah aja, itu mobil yang biru, baju yang bagus itu, dsb.

Pada perkembangan frasa preposisional, belum semua preposisi telah dikuasai responden. Pada umumnya preposisi yang dikuasai adalah yang monomorfemis dan itupun belum semuanya. Preposisi yang sudah dipakai responden di antaranya seperti di-, ke-, buat (untuk).

\section{Perkembangan Kalimat Tunggal Anak Usia Lima Tahun}

Perkembangan kalimat tunggal lebih dikuasai bila dibandingkan dengan kalimat majemuk. Bentuk kalimat aktif jauh lebih dominan dikuasai dibandingkan dengan kalimat pasif. Untuk menyatakan aspek temporal, responden lebih sering memakai kata lagi daripada sedang, sehingga kalimat tersebut lebih sering ditemukan, seperti, aku lagi mandi, mama lagi ke kampus, dan lagi makan di rumah.

Bentuk kalimat interogatif yang dikuasai responden hampir semua kata yang sudah dipakai, seperti kata apa, siapa, berapa, mana, gimana, dan kenapa.

Bentuk kalimat negatif yang sering digunakan responden adalah enggak. Kata tidak baru muncul dan belum sering digunakan. Hal ini mungkin disebabkan oleh banyaknnya penggunanaan ragam bahasa informal dibandingkan ragam bahasa formal. Ragam bahasa formal hanya sering digunakan responden saat ia sekolah

Untuk kalimat imperatif, responden sudah memulai menambahkan penanda kehalusan seperti pemakaian kata tolong, dan mengungkapkan kalimat larangan menggunakan kata jangan, sedangkan untuk bentuk eksklamatif dalam mengungkapkan perasaan senang, sedih, dan marah, responden sudah menggunakan kata aduh, aow, ih, dsb. Kenyataannya ragam bahasa responden adalah informal, tampaknya telah membuat responden memeroleh kata "penyedap" seperti sih, dong, nih, kok, dan lho.

\section{Perkembangan Kalimat Majemuk Anak Usia Lima Tahun}

Pada perkembangan kalimat majemuk setara, responden lebih dominan menggunakan bentuk perurutan, namun belum (tidak) menggunakan konjungsi lalu ataupun kemudian, tetapi menggunakan konjungsi terus. Dari tiga belas kalimat majemuk bertingkat, yang sudah dipakai responden sebanyak lima, yakni waktu, syarat, penyebab, aktif, dan tujuan. Kalimat majemuk waktu adalah yang sering digunakan responden dibanding yang lain, namun bentuk yang memakai konjungtor waktu, macamnya pun masih terbatas, diantaranya konjungsi besok, tadi, kemarin, dan sekarang. Kalimat majemuk aktif, yang memakai konjungtor padahal sudah mulai muncul tetapi belum cukup dikuasai.

Ada empat konjungtor kalimat majemuk syarat, yaitu kalau, jika, bila, dan bilamana. Dari keempat konjungtor itu, hanya kalau (kalo) yang sudah dipakai dan dikuasai dengan benar oleh 
responden. Kalimat majemuk yang menyatakan tujuan dapat diungkapkan dengan konjungtor seperti biar, agar, supaya. Dari jumlah ini yang sudah dikuasai responden hanya satu, yaitu konjungtor biar.

Deskripsi data dimaksudkan untuk memberikan gambaran tentang data yang diteliti. data yang diteliti adalah rekaman audio dan visual anak usia lima tahun. Berikut akan disajikan hasil penelitiannya.

Tabel 1. Temuan Pemerolehan Sintaksis pada Anak Usia Lima Tahun

\begin{tabular}{|c|c|c|c|c|c|c|c|}
\hline \multirow{3}{*}{ No } & \multirow{3}{*}{ Kalimat } & \multicolumn{6}{|c|}{ Sintaksis } \\
\hline & & \multicolumn{4}{|c|}{ Frasa } & \multicolumn{2}{|c|}{ Kalimat } \\
\hline & & $\begin{array}{l}\text { Frasa } \\
\text { Verba }\end{array}$ & $\begin{array}{c}\text { Frasa } \\
\text { Adjektiva }\end{array}$ & $\begin{array}{c}\text { Frasa } \\
\text { Nomina }\end{array}$ & $\begin{array}{c}\text { Frasa } \\
\text { Preposisional }\end{array}$ & $\begin{array}{l}\text { Kalimat } \\
\text { Tunggal }\end{array}$ & $\begin{array}{c}\text { Kalimat } \\
\text { Majemuk }\end{array}$ \\
\hline 1. & $\begin{array}{l}\text { HGF: ma, tadi } \\
\text { aku abis dari } \\
\text { rumah azka. } \\
\text { Terus aku dikasih } \\
\text { hadiah sama } \\
\text { uminya Azka. }\end{array}$ & 1 & & & 1 & & 1 \\
\hline 2. & $\begin{array}{lrl}\text { HGF: kak, aku } \\
\text { pinjam } & \text { HP } & \text { nya } \\
\text { dong. } & & \end{array}$ & 1 & & & & 1 & \\
\hline 3. & $\begin{array}{l}\text { HGF: tadi aku di } \\
\text { sekolah abis buat } \\
\text { bendera. Ini } \\
\text { benderanya buat } \\
\text { mama. }\end{array}$ & 1 & & & 1 & 2 & \\
\hline 4. & $\begin{array}{l}\text { HGF: Abi, aku } \\
\text { mau beli jam } \\
\text { imoo nanti terus } \\
\text { nanti aku mau } \\
\text { pake ke sekolah. }\end{array}$ & 2 & & & 1 & & 1 \\
\hline 5. & $\begin{array}{l}\text { HGF: mama, } \\
\text { nanti kita nginap } \\
\text { di hotel lagi ya, }\end{array}$ & & & & 1 & 1 & \\
\hline 6. & $\begin{array}{l}\text { HGF: tadi aku } \\
\text { dari rumah } \\
\text { Abizar, trus aku } \\
\text { dapat bingkisan. }\end{array}$ & & & & 1 & & 1 \\
\hline 7. & $\begin{array}{l}\text { HGF:aku mau } \\
\text { naik kuda ya. }\end{array}$ & 1 & & & & 1 & \\
\hline 8. & $\begin{array}{l}\text { HGF: mama } \\
\text { kalau kerja jangan } \\
\text { lama dong nanti } \\
\text { aku marah ni. }\end{array}$ & 1 & 1 & & & & 1 \\
\hline 9. & $\begin{array}{l}\text { HGF: kakiku } \\
\text { sakit jatuh dari } \\
\text { sepeda }\end{array}$ & & & 1 & 1 & 1 & \\
\hline 10. & $\begin{array}{l}\text { HGF: aku mau } \\
\text { pakai baju polisi } \\
\text { sama } \\
\text { akmal }\end{array}$ & 1 & & 1 & & 1 & \\
\hline 11. & $\begin{array}{l}\text { HGF: aku mau } \\
\text { ikut jemput kak } \\
\text { Ali ya ke sekolah }\end{array}$ & 1 & & 1 & 1 & 1 & \\
\hline 12. & $\begin{array}{l}\text { HGF: li, kamu } \\
\text { mau kemana? }\end{array}$ & & & & & 1 & \\
\hline
\end{tabular}


13. HGF: ma..masak

dong ini. Ayo cepetan

14. Gahni: Ali..tuh ada keretanya

15. HGF: di situ nanti dia lewat situ

16. HGF: wah keren bgt

17. HGF: aku mau pergi ke hotel lagi ya besok, nanti aku ajak bunda, abi, sama uti.

18. HGF: aku mau nonton ke bioskop lagi ya ma, terus aku mau nonton film lion king lagi.

19. 'HGF: nanti mama jemput aku ke sekolah ya, terus kita jemput kakak Ali di sekolah.

20. HGF: kemarin aku ke hotel, (tanpa dan) aku suka banget.

21. HGF: itu lihat ada kura-kura di situ

22. HGF: ah mama, ayo aku mau naik kereta

23. HGF: sudah habis, aku kasih makan lagi ya rusanya.

24. HGF: hai gajah, aku engga mau naik gajah, soalnya aku takut.

25. HGF: itu..itu ada rusanya

26. Mama: tadi HGF di sekolah blajar apa?

HGF: tadi aku gambar sama aku buat bendera

27. HGF: mama, ke kampusnya cepat ya. Ga boleh lama.

1

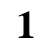

1

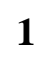

1 
28. HGF: aku mau ke

kota mini lagi ya,

aku suka di sana

seru.

29. HGF: mama..aku

mau minum teh

sama makan jagung.

30. HGF: ma, qiya minta chiki aku mulu nanti chikiku habis.

31. HGF:besok aku sama temanteman mau pergi ke taman honda.

32. HGF: aku berani naik kereta gantung. Aku mau naik ya.

33. HGF: aku engga

mau pergi ke rumah sakit, aku sudah sembuh.

34. HGF: aku sudah bisa naik sepeda.

35. HGF: ma..aku mau sholat ke masjid terus aku nanti dianter ya.

36. HGF: aku mau pakai baju batman

37. HGF: besok aku mau bawa nasi, jagung, sama ikan terus aku makan di sekolah.

38. HGF: mama mau pergi kemana aku?aku ikut ya.

39. HGF: Jangan ambil sepedaku nanti mamaku bisa marah.

\begin{tabular}{ccccccc}
\hline Jumlah & 37 & 12 & 17 & 21 & 28 & 24 \\
\hline Persentase & $26.7 \%$ & $\mathbf{8 . 6 \%}$ & $12.2 \%$ & $15.1 \%$ & $20.1 \%$ & $17.3 \%$ \\
\hline
\end{tabular}

Berdasarkan data deskripsi hasil penelitian di atas, berikut akan penulis gambarkan analisis temuan dan pembahasannya.

\section{Frasa Verba}

Temuan:

Data 1:

HGF: ma, tadi aku abis dari rumah azka. Terus aku dikasih hadiah sama uminya Azka.

Data 2:

HGF: kak, aku pinjam HP nya dong. 
Data 4:

HGF: Abi, aku mau beli jam imoo nanti terus nanti aku mau pake ke sekolah.

Analisis: Frasa verba dalam kalimat percakpan di atas berupa bentuk frasa verba: aku dikasih, aku pinjam, mau beli, dan mau pake merupakan contoh frasa verba yang mengandung pewatas depan atau pewatas kiri verba.

2. Frasa Adjektiva

\section{Temuan:}

Data 8:

HGF: mama kalau kerja jangan lama dong nanti aku marah nih.

Data 17:

HGF: Wah..keren banget.

Data 21;

HGF: kemarin aku ke hotel, (tanpa dan) aku suka banget.

Analisis: Frasa adjektiva pada percakapan di atas, yaitu marah nih, keren banget, suka banget menunjukkan kata sifat bentuk superlatif namun bentuk yang digunakan masih dalam bentuk ragam informal. Pewatas kanan yang digunakan yaitu kata banget.

\section{Frasa Nomina}

\section{Temuan:}

Data 9:

HGF: kakiku sakit jatuh dari sepeda

Data 11:

HGF: aku mau pakai baju polisi sama kayak akmal

Data 15:

HGF: Ali..tuh ada keretanya

Analisis: Bentuk frasa nomina pada percakapan di atas, yaitu kakiku, baju polisi, dan keretanya. Ketiga frasa tersebut menunjukkan kelas kata nomina.

\section{Frasa Preposisional}

\section{Temuan:}

Data 1:

HGF: ma, tadi aku abis dari rumah azka. Terus aku dikasih hadiah sama uminya Azka.

Data 3:

HGF: tadi aku di sekolah abis buat bendera. Ini benderanya buat mama.

Data 5:

HGF: mama, nanti kita nginap di hotel lagi ya,

Analisis: Bentuk frasa preposisional pada percakapan di atas, yaitu dari rumah azka, di sekolah, dan di hotel. Ketiga bentuk frasa tersebut menunjukka kelas kata depan atau preposisi.

\section{Kalimat Tunggal}

\section{Temuan:}

\section{Data 2:}

HGF: kak, aku pinjam HP nya dong.

Data 13:

Li...kamu mau kemana?

Data 14:

HGF: ma..masak dong ini. Ayo cepetan.

Analisis: Pada data di atas terdapat tiga bentuk kalimat tunggal, data 2 menunjukkan bentuk kalimat tunggal yang berfungsi sebagai kalimat deklaratif; data 13 menunjukkan bentuk kalimat tunggal yang berfungsi sebagai kalimat interogatif; dan data 14 menunjukkan bentuk kalimat tunggal berfungsi sebagai kalimat imperatif.

\section{Kalimat Majemuk}

\section{Temuan:}

Data 4:

HGF: Abi, aku mau beli jam imoo nanti terus nanti aku mau pake ke sekolah.

Data 6:

HGF: tadi aku dari rumah Abizar, terus aku dapat bingkisan.

Data 25: 
HGF: hai gajah, aku engga mau naik gajah, soalnya aku takut.

Analisis: Pada data di atas menunjukkan bentuk kalimat majemuk, yaitu berupa kalimat majemuk setara dan kalimat majemuk bertingkat. Pada data 4 dan data 6 merupakan contoh kalimat majemuk setara yang menyatakan perurutan, menggunakan konjungsi terus (bentuk formalnya, yaitu lalu). Pada data 25 merupakan contoh kalimat majemuk bertingkat yng menyatakan makna penyebab, menggunakan konjungsi soalnya (bentuk formalnya, yaitu karena).

\section{Simpulan}

Pemerolehan sintaksis yang paling dominan adalah pemerolehan frasa, yaitu sebanyak $62.6 \%$ dengan rincian frasa verba $26.7 \%$, frasa adjektiva $8.6 \%$, frasa nomina $12.2 \%$, frasa preposisional $15.1 \%$; pemerolehan kalimat tunggal sebanyak $20.1 \%$; dan pemerolehan kalimat majemuk sebanyak $17.3 \%$.

Perkembangan frasa HGF yang berusia lima tahun sudah berkembang lebih baik terutama frasa verba, unsur pewatas depan sudak banyak dikuasai subjek, seperti mau main, belum punya, sudah habis, dan sebagainya. Perkembangan kalimat tunggal pada anak usia lima tahun jauh lebih dikuasai bila dibandingkan dengan penguasaan kalimat majemuk.

Penelitian ini masih terbatas pada pemerolehan sintaksis pada anak usia lima tahun karena keterbatasan waktu, tempat, dan dana. Pemerolehan sintaksis yang paling dominan adalah pemerolehan frasa dibandingkan dengan pemerolehan kalimat pada anak. Perkembangan frasa pada anak usia lima tahun sudah berkembang lebih baik terutama frasa verba, unsur pewatas depan sudak banyak dikuasai responden, seperti mau main, belum punya, sudah habis, dan sebagainya. Perkembangan kalimat tunggal pada anak usia lima tahun jauh lebih dikuasai bila dibandingkan dengan penguasaan kalimat majemuk.

\section{Ucapan Terima Kasih}

Penulis mengucapkan terima kasih kepada semua pihak yang telah membantu penulis dalam menyelesaikan artikel ini, terutama kepada subjek penelitian penulis, yaitu Husein HGF Fakhrusy dan kedua orang tuanya yang telah memberikan tenaga dan waktunya untuk bersedia diwawancara dan diobservasi segala aktivitasnya.

\section{Daftar Rujukan}

Bassey, Michael. Case Study Research in Educational Settings. McGraw-Hill Education (UK), 1999.

Candrawati, Ni Luh Komang. Medan makna rasa dalam bahasa Bali. Pusat Bahasa, Departemen Pendidikan Nasional, 2008.

Chaer, Abdul dan Agustina Leoni. Sosiolinguistik. Jakarta: PT Rineka Cipta, 2004.

Chaer, Abdul. Psikolinguistik: Kajian Teoritik. Jakarta: PT Rineka Cipta, 2009.

Chaer, Abdul. Sintaksis Bahasa Indonesia. Jakarta: PT Rineka Cipta, 2009.

Dardjowidjojo, Soenjono. Psikolinguistik: Pengantar Pemahaman Bahasa Manusia. Yayasan Pustaka Obor Indonesia, 2003.

Dardjowidjojo, Soenjono. Echa: Kisah Pemerolehan Bahasa Anak Indonesia. Jakarta: Grasindo, 2010.

Nawawi, Hadari. Metode Penelitian Bidang Sosial. Gadjah Mada University Press, 1993.

Nurjamiaty. "Pemerolehan Bahasa Anank Tiga Tahun Berdasarkan Tontonan Kesukaannya Ditinjau dari Konstruksi Semantik." Jurnal Unimed (2015).

Tarigan, Henry Guntur. Pengajaran pemerolehan bahasa. Penerbit Angkasa, 2011.

Usman, Hakim. "Studi Pemerolehan Bahasa Pada Anak Usia 4 Tahun (Kajian Sintaksis)." Jurnal Linguistik Terapan 5.2 (2015): 16-28.

Wulandari, Desy Indah. "Pemerolehan bahasa Indonesia anak usia 3-5 tahun di PAUD Lestari desa Blimbing kecamatan Paciran kabupaten Lamongan." Lingua Franca: Jurnal Bahasa, Sastra, dan Pengajarannya 2.1 (2018)

Sari, Meliana. "Meningkatkan Pemahaman Orang Tua Dalam Menstimulasi Perkembangan Bahasa Anak Usia Dini Melalui Program Parenting." 2015. repository.upi.edu. perpustakaan.upi.edu. Juni 2020. <http://repository.upi.edu/17645/4/T_PAUD_1302918_Chapter1.pdf>.t.thn. 